Sherwood, Peter. "Sándor, Klára. 2017. A székely irás reneszánsza ['The Renaissance of the Székely Script']. Budapest: Typotext. 311 pp." Hungarian Cultural Studies. e-Journal of the American Hungarian Educators Association, Volume 11 (2018) DOI: 10.5195/ahea.2018.343

\title{
Sándor, Klára. 2017. A székely írás reneszánsza ['The Renaissance of the Székely Script']. Budapest: Typotext. 311 pp.
}

\author{
Reviewed by Peter Sherwood", László Birinyi, Sr. Distinguished Professor of Hungarian \\ Language and Culture (Emeritus), University of North Carolina at Chapel Hill
}

This is the third of the author's books to be devoted to Hungarian myth and early (cultural) history focussing on the analysis and cultural-historical context of the distinctive and mysterious script from the Székely (Szekler) area of Transylvania. The Székelys today number perhaps half a million people and have for centuries lived mostly in Romania's eastern Carpathian counties of Kovászna/Covasna, Hargita/Harghita, and Maros/Mureș. Though they form a distinct part of the Hungarian people, with their own mythology, history, laws and customs going back a thousand years, they have never, as far as is known, spoken any language other than Hungarian and must be counted with the Hungarian minority totaling some 1.25 million that remain in Transylvania today.

The first of the three volumes, which fit together as satisfyingly as any jigsaw or mosaic, is Nyelvrokonság és hunhagyomány ['Linguistic Kinship and the Hun Tradition'] (Budapest: Typotext, 2011; see my review of this work at: http://ahea.pitt.edu/ojs/index.php/ahea/article/view/101). In this work she lays out the broad linguistic, mythological, literary, historical and cultural background to the evolution of the Hun tradition, particularly its Turkic elements. Those new to this topic should bear in mind that "Turkic" is not to be confused with "Turkish," a term reserved for the later (Ottoman) Turks and their language.

In the second volume of the trilogy, A székely írás nyomában ['On the Tracks of the Székely Script'] (Budapest: Typotext, 2014; see my review of this work at:

https://ahea.pitt.edu/ojs/index.php/ahea/article/view/203/343), she concentrates more specifically on the origins and strata of the script, which is still often and, as she argues, erroneously referred to as "runic" and/or the "Old Hungarian" script, and investigates its possible Turkic connections, theories of its origin, and the research on it so far, as well as providing a preliminary classification of its genres. Regarding this last point, it should be noted that the much-needed catalogue raisonné of the complete records of the script, promised in this book and again on page 10 of the latest work, has not so far appeared.

While many question marks still surround the script and especially its origins, Klára Sándor's meticulous scholarship and polymathic erudition has added a vast amount of reliable information to our knowledge. Not least, while giving credit where credit is due to her

*magyarize@gmail.com

$($ (c) $)$ EY

ULIS D-Senke
New articles in this journal are licensed under a Creative Commons Attribution 4.0 International License.

This journal is published by the University Library System of the University of Pittsburgh as part of its D-Scribe Digital Publishing Program and is cosponsored by the University of Pittsburgh Press 
Sherwood, Peter. "Sándor, Klára. 2017. A székely írás reneszánsza ['The Renaissance of the Székely Script']. Budapest: Typotext. 311 pp." Hungarian Cultural Studies. e-Journal of the American Hungarian Educators Association, Volume 11 (2018) DOI: 10.5195/ahea.2018.343

predecessors as well as her contemporaries in the field, she has wittily skewered dilettante speculations about the script, as well as the risible (though telling and relevant) political, notably right-wing, appropriations of it. At the same time, she has consistently provided a reliable and enjoyable introduction to early Hungarian cultural history, a vast field hitherto often the province of dry-as-dust tomes.

In this third work the author investigates the relevance of the two earliest records of the script so far discovered outside the Székely lands to the "cult" that it enjoyed in the court of Hungary's famed Renaissance king, Matthias Corvinus (reigned 1458-1490). These documents date from the second half of the fifteenth century and are known, after the places where they were found in the twentieth, as the Székely Alphabet of Nikolsburg (today's Mikulov in Moravia, Czech Republic) and the Bologna Document (which the author, in her 1991 dissertation, still called the Bologna Runic Document, that date giving some indication of how long this topic has held the author in its thrall). The former is just a single sheet with a Székely alphabet drawn, rather than "written," on it, with a Hebrew alphabet added somewhat later underneath, apparently in the awareness that both scripts are read from right to left. The latter, however, at eight manuscript pages in length, is the longest and most valuable record of Székely writing so far discovered. In one of the most remarkable sections of the book, the author persuasively argues that this document was copied down by the indefatigably inquisitive polymath, soldier, diplomat and passionate collector of antiquities Count Luigi Fernando Marsigli (1658-1730) when, over the winter of 1690-1, he was confined to the ancient castle of the Lázárs at Szárhegy/Lăzarea, just north of Gyergyószentmiklós/Gheorgeni, and became fascinated by a fifteenth-century manuscript, long since destroyed, shown to him by monks at the nearby Franciscan monastery. (The book is strong on the vital contribution of the Franciscans to medieval and early modern Hungarian culture).

The "Székelyland tradition" to which the authentic, usually quite short, examples of the Székely script belong and have nearly all been found in churches in the Székely region should be distinguished from the "court tradition" of these two documents. It is the complex but fascinating links between the two traditions that Klára Sándor's new book explores. She does this by providing reproductions of the documents (reasonably reproduced here but really needing to be enlarged and perhaps printed on glossy paper) and subjecting them to rigorous codicological and palaeographical analysis, while simultaneously placing them in the broad yet detailed context of contemporary Hungarian-language records and carefully following the historico-cultural trails necessary to shed light on them.

The book contains so many insights into a wide range of topics that it is impossible even to hint at them in this brief review. But perhaps the most thought-provoking is the section building on the author's 2011 volume that shows how the historians at the Renaissance court of Matthias recast the ancestry of the ruler (and subsequently the Hungarian nobility and, ultimately, the entire Hungarian people) as stemming from a "Scythian-Hun" tradition, which enabled Matthias, who was in fact the scion of a noble family probably of Romanian origin, to present himself as "Attila redivivus." In this startling transformation of the "scourge of God" into a quintessential Renaissance prince a crucial role was played by the (re)discovery and appropriation of the distinctive Székely script. According to the court chroniclers the Székelys were descended from the Huns (who in turn were descended from the Scythians), so they cannot have been the ignorant barbarian horde of, especially, western tradition, as they already 
possessed their own, curious script. Moreover, this script must have been very ancient, since it was originally written not on paper but, the chroniclers claimed (on what Klára Sándor demonstrates is not conclusive evidence), on wooden sticks. That the Székelys - traditionally the most pristine of Hungarians - retained the script of their Hun ancestors was proof positive that the Magyars ultimately originated from Scythia, linking them to the world of antiquity while endowing them with a unique past. Elements of this mythopoeic narrative continue to shape what the Hungarian man-in-the-street knows about the Székelys and their (allegedly "runic," "Old Hungarian") script, giving some indication of how these myths have been, and continue to be, intertwined with Hungarian history and thus with Hungarians' perceptions of their past and present.

Like the previous two volumes in the trilogy, this is a rigorous work of scholarship, with almost nine hundred footnotes and the by now usual thirty-page bibliography; yet the author's inexhaustible enthusiasm for her subject and racy style makes it, as she herself is very much aware, an exciting piece of philological detective work. She has indeed created a unique genre. It is, however, at times hard to keep up with the welter of data about people, places and documents, and there are numerous avenues that are sometimes perhaps too relentlessly explored in a 270page text divided into only five main sections (so that each is on average over fifty pages long). Moreover, as I have had occasion to remark before, the sections in her books are unnumbered and no index of any kind is provided, making this book, like her others, difficult to use as the work of reference that it (also) aspires to be. So, when I stress once again the importance of making the author's work available in a major language, I must add that not only will chapter numbers and indices be essential but the material will have somehow to be edited down to more manageable proportions, even at the regrettable cost of losing some of the fine and delightful detail. Perhaps, though, it is now time to fashion a new publication out of the three Hungarian originals, for a specifically English-language readership. For Klára Sándor's valuable and highly original work richly deserves international recognition. 